\title{
THE INCREASING OF SELF-CONCEPT THROUGH RET ON SUBJECT ID: AS A VICTIM OF DRUG ABUSED AT JAYAGIRI VILLAGE, LEMBANG SUB-DISTRICT, BANDUNG BARAT REGENCY
}

\author{
Anandri Novan Pratama \\ Dinas Sosial Kabupaten Bandung Barat, PPKH Kabupaten Bandung Barat, \\ anovanp@gmail.com \\ Admiral Nelson Aritonang* \\ Politeknik Kesejahteraan Sosial (POLTEKESOS) Bandung, nelsonaritonang@yahoo.com \\ Epi Supiadi \\ Politeknik Kesejahteraan Sosial (POLTEKESOS) Bandung, episupiadi@yahoo.com \\ Note: *correspondence
}

\begin{abstract}
This study aims to examine the effect of Rational Emotive Therapy (RET) on the improvement of self-concept in the subject ID of victims of drug users. Perceptions reflected in the subject's internal and external behaviors that lead to the disruption of their self-concept are the focus of the intervention in this study. The research approach used is quantitative research using Single Subject Design (SSD) or $N=1$. The research model used is $A-B-A$ which occurs from three phases, among others, Phase A1 (baseline), Phase B (Intervention), and phase A2 (results). The instrument used is a questionnaire developed by researchers based on the theory of William H. Fitts. Data collection techniques used are in-depth interviews, questionnaires, and documentation studies. The data obtained was analyzed by charting and making descriptive statistics. The results showed that the application of Rational Emotive Therapy (RET) succeeded in improving self-concept which previously made subjects not adaptive to the environment. Changes that occur after subject therapy experience an increase in self-concept shown by the reduction of irrational thoughts and subjects become more adaptive to their environment. This research recommendation can be continued to look at the effect of RET therapy in handling the problems of self-concept of victims of drug users in the future and can contribute ideas in the development of social work science in dealing with drugs.
\end{abstract}

Keywords: Self-Concept; Rational Emotive Therapy (RET); Drugs 


\section{INTRODUCTION}

Drug abused in Indonesia is a big threat for the youth generation and the continuity of nation's life. It is the complex problem in terms of cause factor and impact. The cause factors involve physical, psychological and social ones. The impact of it is very big that is social burden, economy and physicology to himself, familiy and social surroundings.

NAPZA is narcotics, psychotropics and addictive substance. Beside that, Napza is dangerous medicines. It is a substance or a medicine. If they enter to the human body, they will influence it especially the composition of brain, central nurve so that there will be a disruption to the physical health, psychological and its social function because it occurs habit, addict and dependency towards NAPZA.

The term of NAPZA is generally used by health service sector which focus on the intervention effort in terms of physical health, psychological and social. Napza in physician term is chronical brain disease that is chronical brain disease which cause mind change, behavior, emotion and attitude that can not be cured.

Nowadays, drug abused has been one of the societal problems that has big impact, not only on the substance dependency bu also on the bad impact just like dual emerges. Untill the third quarter of the year 2018, there is 48 cases of drug abused and drug circulation occured in Bandung Barat regency. Red zones of drug abused and drug circulation in Bandung Barat regency spread into 4 sub-districts: Lembang, Ngamprah, Padalarang and Cililin sub-distric.
The Head of National Narcotics Agency Bandung Barat Regency, Sam Norati Martiana said that 48 drug abused cases and drug circulation cases that was handled by BNN and Cimahi headquarter police. The total number for drug cases that was treated by BNN is 7 cases that occured in Lembang. It was about 50 precentage of drug abused in Bandung Barat Regency as the following: 27 $\%$ is student and $23 \%$ is general society. At past the men drug abused is very dominant, today the total number of man and woman is almost the same.

Nowadays, the problem of drug abused has changed in status to be national disaster. It is signed by the program "Indonesia drug emergency" by President Republik of Indonesia, MR. Ir. H. Joko Widodo. This was because of the increasing of the total number of drugs abused, the problem complexity or the type of substance abused. According to data from Badan Narkotika Nasional (BNN) Bandung Barat regency, dated since may, 2018, there was 17 dealers of drug had been caught in Lembang sub-district area. In Jayagiri village, there were 7 people caught by Babinsa, each using meta-methamin and kanabioid.

The doer of drug abused in Jayagiri village aged under 20 years and above 30 years. However, most are ranged from the late or teenagers and early adult. The victims of drug abused have various job: Nongovernment official, enterprenership, students, jobless, and the others. From the educational level, the highest education is S1 degree and the lowest is junior high school. The place where the transaction occurred: crowded place such as market, place of 
residence, school/campus surroundings, and so on.

\section{Badan Narkotika Nasional (BNN)} Bandung Barat regency provides rehabilitation program integrated with public health centre for 19 peop;e located in Jayagiri village, Lembang sub district with the medical official,s dr. Suci. But the victim of drug abused who had enrolled to be rehabilitated had not achieved the hope target.

The government had launched several policies and prevention program of the intervention of drug abused. One of the programs was "National Movement for rehabilitating one hundred thousand victims of drug abused “. Unfortunately, BNN Bandung Barat Regency had not program directed to prevent the spread of revolving of drug abused. Prevention efforts and the intervention of drug abused could not be done by 1 leading sector. It was needed the cooperation from various sectors either government or non-gevernment. To reach rehabilitation program, gevernment launched 4 policies as the following:

1. The rule with the head of Supreme Court of Republic of Indonesia, the minister of law and human basic rights, The minister of health of republic of Indonesia, The minister of social affairs of Republik of Indonesia, Great Prosecutor of Republic of Indonesia and the Head of BNN of Republic of Indonesia, number 01/PB/MA/III/2014, 03 Tahun 2014, 11

Tahun 2014, 03 Tahun 2014, PER005/A/JA/03/2014, 1 Tahun 2014, PERBER01/III/2014/BNN;

2. The rule of Health minister of Republic of Indonesia Number 2415 The year
2011 about drug medical rehabilitation for the addiction, and the victim of drug abused;

3. The rule of the minister of social affairs number 56 The year 2009 about service and social rehabilitation for drug abused; and

4. Government rule Numbered 25 The year 2011 about executor report obligation for narcotics addiction.

The policy governs about the rehabilitation execution medically and socially for the victim of drug abused through the IPWL. There is west-java province local rule number 25 The year 2012 about Prevention and social rehabilitation for the victim of drug abused. The problem of Drug abused in Jayagiri Village becomes the focus of the vulnerable area toward drug abused problem because many cases of it. The result of early assessment which is conducted in participatory method (community meeting) and Non-participatory method (informal interview, observation, transectwalk and documentation study) shows that jayagiri Village area is vulnerable towards drug abused.

Some considerations which becomes the reasons why Jayagiri village as research location namely Jayagiri village had ever been frisked for drug use cases by BNN, a lot of locations become places to consume alcohol, glue and dextro (komix) which is over the suggestion, to fight and gamble, to be lack of society's knowledge and to understand on drug abused, to have no supporting of society and social control. Most of the drug abuse user in the area of Jayagiri village are dominated by teenager aged 14-20 yaers old, according to cases data from 
BNNK Bandung Barat. The age of teenager is unstabil personality, period of where they look for self-actualisation and they want to try something new in their life.

The period of unstabil personality if it is uncontrollable so it will be vulnerable to get bad situation like becoming a victim of various mis-treatment and exploitation such as physical violence, criminal activity, drug abused, Sexual object and many more. Those will influence the forming of self concept on children. Social environment or the pattern of taking care is one factor of forming one selfconcept. Self-concept can be understood as one's ability to evaluate himself. It is needed by everyone because uncounciously complex problem faced by human aroused from himself (Rini, 2000). They create uncounsiously problem's chain aroused from self-concept or individuual's ability to evaluate himself. $\mathrm{He}$ is able to think and evaluate various things on himself or others and believe his perception which is not sure objectively. Therefore, the problem aroused like inferiority, lack of self-confidence and self-criticism.

Before th process of research, researcher had done specialist practicum activity and focused on the victim of drug abused, depressant and halusinogen types. The research conducted by Arden lee, C. wirrel, titled pediatric neorology: self concept in adolescents with drug users (vol.38 pg. 335) described drug user with halusinogen describes that drug user in the range of 2 years and with the often use can disturb self cocncept on the abstinent period. Self concept disturbance aroused from the use of drug with the type of halusinogen than influence the central -nerve system that manage thinking consciuosnes and logical thinking. They consider that what they think is the reality form that must face nowadays.

In the practical process, I discovered drug user' problem who had self concept disruption because of the use halusinogen and depressant, namely "ID", a late teenager aged 18 years. ID behavior is considered deviant by the society because of drug abused and unwillingness of ID to socialize with the society make him to be more excluded by surrounded society. ID was scarely at home and more choosed to gather with his drug abused friends. It infact made ID'parent uncomfortable because of the neighborhood or head of neighborhood always addressed but they say that it was not always consired and he tended to be busy with his own world. He considered that his friends more accepted his condition and appreciated so he was more enjoyable with them. They did not care on his performance and thinking describing that he was useless in its social environment Referring to the condition and the characteristic of "ID". He is identified selfconcept disruption.

In handling this problem, some opinions are developed. There are two views on seeing how self-concept on oneself can occur. The biological and sociocultural factors cause the process of one' cognitive. Beside that, it occurs because of the process of one's thinking so client has the new thinking. The researcher tries to analyze from the client's cognitive using Rasional Emotif Terapi (RET). Rasional Emotif Terapi (RET) is one type of intervention which is valued can change of human behavior by changing of client' belief by the method of reconstruction of client's cognitive. Some 
intervention procedures can be choosed according to the thinking method problem experienced by client. The combination of many techniques coming from behavior change approach is combined with model procedure coming from behavioral cognitive approach. Result evaluation of practicum activity in Jayagiri village showed lack of impact on client who hasd been intervened. The purpose of Intervention which iwas given to the client was making him to be able of self- reliance reducing negative selfconcept experienced by client ID. But it is cold only work for the first week after doing the second intervention on client using Rational Emotive Therapy. Based on the the result of reassessment conducted by the researcher, macro intervention on client "ID" using Emotive Rational Therapy with the purpose of reducing nclent's egative selfconcept. It is only able to change internal aspect. However, Fitts (Agustiani, 2006) selfconcept is divided into two dimensions, namely internal and external dimensions. However, in order to get maximum result in the intervention process, hoping that there was goal intervention to touch external dimension of client ID. The researcher usds self concept theory from Fitts (2006) because it was considered more comprehensive, relevant and more details.

Not only focusing on the use of RET in changing behavior ID but also doing the effort of capacity building toward external dimension on family and community in supporting and strengthen new behavior that is later emrges. Social support from the environment can strengthen ID in developing new behavior. Based on the background, I am interested in conducting research about The
Increasing Self-Concept through Emotive Rational Theory on client ID experiencing negative self-concept disruption in Jayagiri Village Lembang sub-district Bandung Barat District.

\section{METHOD}

The research uses Quantitative resrch method. It is an experimental research with Single Subject Design (SSD) where N=1 with model A B A. Experimental research is trial activity to see whether is there intervention influence or treatment on target behavior. Research subject is something that is the target of research. Creswell (2009:159) describes that single subject research is the research with single subjevt with the research procedure using experimental design to see the influence of the intervention implementation toward behavior change. The single Subject Design, known as SSD, is evaluation method which is more used in social work practice. In direct service with the purpose of evaluating subject behavior change after giving intervention in the period of time determined. Comparison is not done between individual in group but it is compared on the same subject with the different condition. Cozby (2009: 328) describes that in Single Subject Design, the subjects behavior is valued long life on one period of baseline.

The research used measurement which is composed by the researcher, including questionnaire about self concept modified based on William H Fitts's theory (in Agustian) The questionaire consists of 8 dimensions and 14 indicators. It is described in Likert scale format. The scales are stated in favorable and unfavorable statements with 
five response alternatives which consist of: deeply agree, Agree. Neutral, disagreement and deeply disagreement. The scale used to measure self concept ID the victim of drug abused experienced self concept disorder. The questionaire used is self concet instrument covering internal dimension divided into 3 aspects and external dimension divided into 5 aspects. The questioners is modified based on the field condition, 60 questioners.

Subject used single subject where the behavior after treatment is compared to the behavior before treatment. Sukmadinata (2005:59) describes the experimental single subject is the experiment conducted to the single subject. Subject is single, it can be one, two peoples or more. Experiment result is presented and analyzed individually. The subject is ID, the victim of drug abused in Jayagiri village, Lembang sub-district. The research activity is the follow up of the practicum so the technique sampling used by evaluating the result of practicum activity.

\section{RESULT}

\section{The description of problem intervention}

The description of problem intervention (ID), the wictim of drug abused is described through the asessment before the intervention process, there are:

\section{The history of problem intervention}

The history of client problem intervention with the drug abused started by medical treatment in the year of 2014, where the client had a serious illness on stomach. At that time, client iwas directly brought to the public health service Jayagiri village where there was service for the patient who was deeply ill. The doctor diagnosed that client experiencing degistion disorder which attacked to kidney and it made the clien feel sick on his stomach. It was becaused of client's often consuming of alcohol. The doctor suggested to lab test and a new fact emerged that client is positive in using drug abused, Finally, he wa referred to National agency of narcotics Bandung Barat regency to have follow-up intervention. After interviewed by doctor, client consumed hemp plant and Methamphetamine in the period of past a year.

BNNK referred the client to have out service accompanied by the doctor Suci. In joining the therapy, client determined amd would to join therapy. There is no coercion from other people. Clien felt bored because he always depended on the problem of drug abused, till at the end, client determined to cope his problem.

\section{The history of drug abused}

The history of drug abused experienced by client began when he was in freshman year at junior high school. Client knew it from the drug store and began to drink alcohol. The history of drug abused continued to senior high school where was the peak and made him to be drop-out school at the sophomore year. In senior high school, he had tried every type of drugs. The ones that had not been tried was injected. 
Table 1 The history of drug abused done by ID is as follows:

\begin{tabular}{|c|l|l|}
\hline No. & \multicolumn{1}{|c|}{$\begin{array}{c}\text { Types of drug } \\
\text { abused }\end{array}$} & $\begin{array}{c}\text { The beginning } \\
\text { year of } \\
\text { consuming }\end{array}$ \\
\hline 1 & Alcohol & 14 years \\
\hline 2 & Hemp plant & 14 years \\
\hline 3 & $\begin{array}{l}\text { Tryhexipenedil, } \\
\text { eximer }\end{array}$ & 14 years \\
\hline 4 & Metha phethamyn & 15 years \\
\hline
\end{tabular}

Source: Researcher data, 2019

\section{Psychological function}

Psychological function is related to client's spiritual condition. It could be seen from the emotional characteristics emerging from client. The explanation of client's psychological condition descriptions could be seen from the table as the following:

Tabel 2 Client's Psychological Condition Descriptions

\begin{tabular}{|c|c|c|}
\hline No & Characteristics & information \\
\hline 1 & Quiet & Client only have limited friends \\
\hline 2 & Unstable emotion & $\begin{array}{l}\text { Sometimes client get angry with his parents and brothers } \\
\text { without clear reason }\end{array}$ \\
\hline 3 & Not confidence & $\begin{array}{l}\text { Client face always gloomy, not confidence to face-to-face } \\
\text { when communicate with others }\end{array}$ \\
\hline 4 & Easy to be influenced & $\begin{array}{l}\text { Easy to provocate with what others told without thinking } \\
\text { about it first }\end{array}$ \\
\hline 5 & $\begin{array}{l}\text { Sometime doing } \\
\text { violence }\end{array}$ & $\begin{array}{l}\text { Based on peoples around him, they said they get violence } \\
\text { from him }\end{array}$ \\
\hline 6 & Bad communication & $\begin{array}{l}\text { Client seemed confused and unfocus, also think long before } \\
\text { answer question given by researcher }\end{array}$ \\
\hline
\end{tabular}

Source: Researcher data, 2019

From the client psychological side, it could be said that his psychological was unstable. Client is quite person and lack of self confidence in the environment or at the time he faced the researcher. Less of client self confidence showed by these characteristics as the following: 
1. Subject could no meet face to face with others.

2. No brave to make argument and do not want to talk to a new person.

3. Easy to be nervous and talk stammered.

4. Always tense when communicating with others.

4. Dimension 7- Structur and family story

Client is the first of 4 brothers. The third brother died when he was in the womb. No brothers are close to him because he was never at home and always played with the peer group. His father is drug abused as well based on the client's information and observation to a lot of sources. The causes of not being at home because uncomfortable subject and the problems with parent, especially his father because subject's trauma experiencing violence case.

\section{Implementation of Rational Emotive Therapy (RET)}

The implementation of RET therapy which will be conducted in three (3) activity stages as the following:

1. Form support emotional (A-B-C)

a. Ask client to think some basic irrasional view that has motivated a lot of behavior disorder.

b. Oppose client to test ideas.

c. Show the client that his opinion unlogical

2. Positive thinking technique (Dispute theory)

In this session the relationship between therapist and client is strong and there is a commitment to involve in dialogues. Some to be done in the second session as the following:

a. Using logical analyses to minimalize client's irrational beleif. b. Showing that belief is useless and how it can make emotional disorder or behavior at the future.

c. Using absurdity and humour to face client' irrational thinking.

3. Competency increasing (Effect theory) This level is the task to help client ID, the victim of drug abused in redeveloped self concept to be the ideal role of parents and external environment as an effective source in increasing competency. On this stage, therapist increase his attention on client in home or out of home to see behavior change.

a. Explain how irrasional ideas can be changed by rasional ideas which has empirical phylosophy and

b. Teach client how to implement science approach on the way of thinking so the client can observe and minimize rational idea and unlogical conclusion.

\section{The result of line Baseline measurement}

To know the effectivity of Rational Emotive Therapy (RET) in increasing self concept ID, that first I conducted data analyses based on questionare, test of subhypothesis and main hypothesis. Based on graphic 1 below describing that self concept of subject ID on the intervention $B$ phase experiencing change. The score is the total score from counting each session on implementing intervention B. It is shown that the increasing occurs on each session. Only phase 4 experiencing stability and there is no score increasing from score 234 to score 232, but at the end of session, there is a significant increasement on self concept that is high category. 


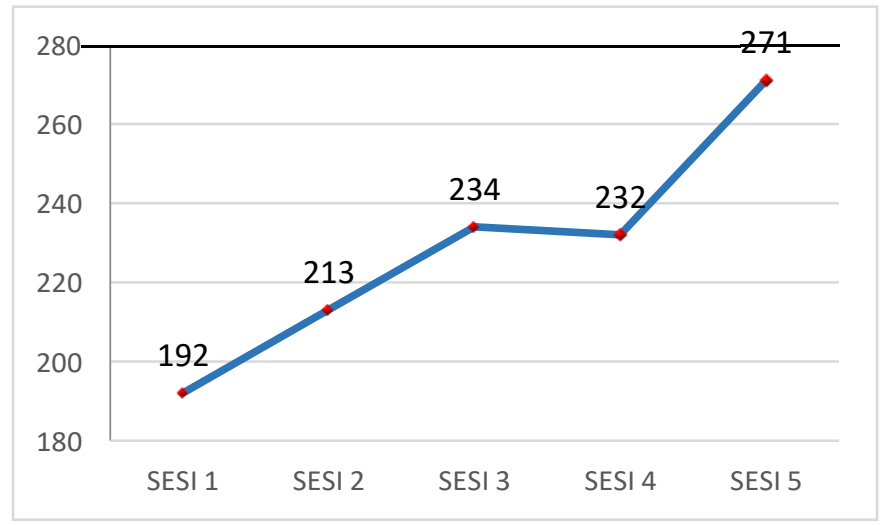

Graphic 1 The Result on the Intervention Phase

From baseline A2 phase, I re-measure self concept of subject AS after conducting intervention process. The process of self concept measurement on baseline A2, I used the same instrument on the baseline phase of A1. The purpose is to know the success level of intervention process. The measurement of baseline A2 phase conducted twicw with the following result:

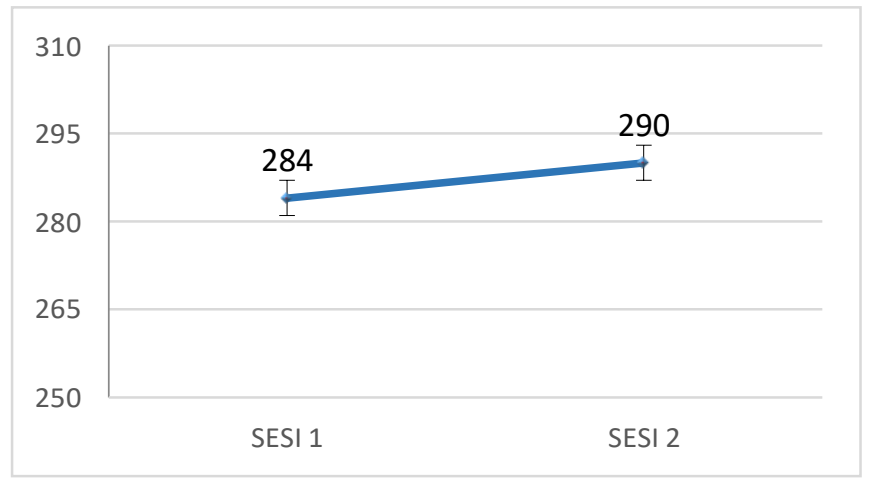

Graphic 2 The Result on the A2

Based on graphic 2 describing that self concept of Subject ID on the measurement of baseline A2 tends to be stabil and increasising. Although the increasing is not significant, but it shows there is consistency of behavior change emerged from the subject ID after doing intervention process. Aspect that will be analyzed that analysis condition such as condition length, direction trend, stability level, change level of data track and the length. The description is as follows:

\section{Condition length}

Condition length shows the total of session conducted in three phases, there are: baseline phase A1, baseline phase $\mathrm{B}$, dan baseline phase A2. Related on it, it can be seen the description of research phase on the following table: 
Table 1. Condition length

\begin{tabular}{|c|c|c|c|}
\hline Kondisi & A1 & B & A2 \\
\hline Panjang kondisi & 2 & 5 & 2 \\
\hline
\end{tabular}

Source: Researcher Data, 2019

The above table shows the process of research phase whis is divided into some phases namely, baseline A1 phase conducted twice, intervention (B) phase conducted 5 times, and baseline A2 phase conducted twice.

\section{2. $\quad$ Direction trend}

Direction trend on this research conducted with the method of splitmiddle namely: a. Divide data from baseline phase into 2 parts which exist between 2 data and divide into two on the left and right sides (A1 left and A2 right)

b. Determine median position from each side

c. Draw the straight line f horizontal and downward with the absis on every session which will be explained in line 3 grahic as the following:

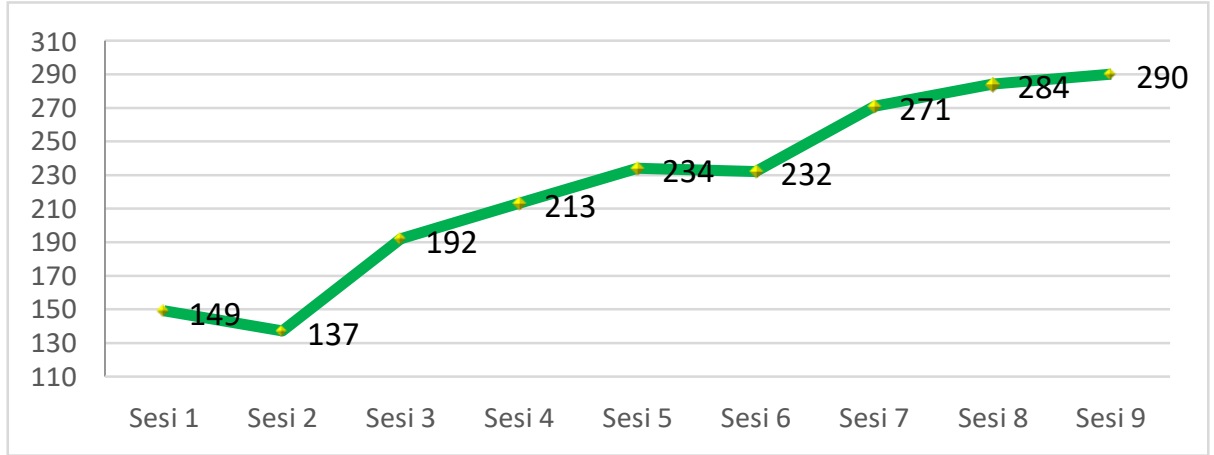

Graphic 3. Direction trend

Graphic 3 described that in session one and session two showed A1 baseline phase, session three to seven are baseline intervention phase (B), and on session eight and nine are $\mathrm{A} 2$ baseline phase. Based on that Graphic the estimated direction tendency data obtained in the following table:

Table 3. Estimated direction tendency

\begin{tabular}{|l|c|c|c|}
\hline Condition & $\mathrm{A}-1$ & $\mathrm{~B}$ & $\mathrm{~A}-2$ \\
\hline $\begin{array}{l}\text { Estimated } \\
\text { direction } \\
\text { tendency }\end{array}$ & $(-)$ & $(+)$ & $(+)$ \\
\hline
\end{tabular}

Source: Researcher Data, 2019 
Positive direction and data stability on session 6 and 7 Baseline A2 phase shows positive direction trend. Based on table 2 describing graphics 3 showing negative direction trend, However the decrease of score is not significant intervention $\mathrm{B}$ phase is as follows.

3. Stabuluty Level and rentang Determining stability level, after doing the count on baseline A1 phase, data got stabil, on intervensi (B) phase stabil enough, and on baseline A2 phase was stabil as well. The range of baseline A1 phase on 149-137, intervensi phase on the range 234271 , and baseline phase A2 on the range 283290.

4. Change Level

Change Level is known by sgning the first day and the last day. If the result is positive showing better direction, but if it shows negative shows that it is decreasing.

Table 4. Change Level

\begin{tabular}{|l|c|c|c|}
\hline Condition & A-1 & B & A-2 \\
\hline \multirow{2}{*}{ Estimation } & $149-$ & $192-$ & $284-$ \\
trend & 137 & 271 & 290 \\
& $(-)$ & $(+)$ & $(+)$ \\
\hline
\end{tabular}

Source: Researcher Data, 2019

\section{DISCUSSION}

The research focuses on the sekf concept disruption problem experienced Subject ID. The phenoma of self concept disorder which emerges from him is unable to socialize with other person, considering he himself is useless, considering the others is more useful, always negative thinking toward himself, unable to accept mistakes, never being satisfied for the self achievement and tend to blame the other. Based on the disorder itself, the discussion of research result, according to internal and external aspects will be explained as the following:

\section{The discussion of internal aspect}

Aspect of self concept studied William H. Fitts (dalam Agustiani, 2006) is divided intothree dimensions in internal aspect which is made questionare to measure self concept subject OD/ The research resukt in details can be seen as the following:

\section{a. Self identities}

Self identity aspect involves labels and given to self by subject ID hinself and develops his identitity. For examples label considered by subject is useless feeling and other more useful than him. This Label attached in line of self concept growth occurred to subject. The first measurement result on pada baseline A1 at first getting score 10, It is the least score of others. Subject ID describes himself as one that is not able to know self potention and feels that he was a coward. It seen from his daily life ID. He considers that he is weak compared to others around him, always to avoid and looks sad when gathering with peer group in his neighborhood surrounding because feel that he was unfit to be there.

The self description got from the consequences of past subject trauma in the child period. Subject usually got rude 
behavior from his parent. Subject was ever said stupid by them because he ever left behind. It makes him fell that he was stupid child. The counting of the second baseline A1 done by the researcher shows the least score, 13. Respondent answer is very low because there is a think that respondent is a useless person.

The implementation of intervention (B) done in 2 days after counting the second baseline A1. respondent response upward although it is still in low category. It is experienced by him because adaptation process on the treatment given by the researcher. Until the fifth intervention implementation session shows that there is the increasing drastically with the score 27 considered high category.

Rational emotif therapy impact given is able to change subjects thinking pattern on life. The success of increasing self concept on self identity showed with subject thinking on recognizing himself as an individual who has the ability and brave. It is shown whenever the subject said about his strength and is able to dig potention with the direction of the reasercher

b. Self behavior

It involves consciuosnee of what has benn done, consisting of consciousness of consequency of behavior has done. Adequate self showed in line with self identity with behavior emerged.

Behavior emerged before therapy is seen clearly because he didn't think about the concequency of his activity done. For examples when he did drug abused, he was unconscious that drug abused will come to dependency.

Self behavior dimension is divided into 2 indicators which is spread into 8 staments items. The measurement of baseline A1first phase and second phase get the lowest score are 15 and 16 of maximal score 40 . The the majority of choice of subject response is agree and disagree and deeply disagree. It shows that he is not in line between action with the effect of activity.

\section{c. Self evalution}

The function of self evaluation is observer, standard determiner and behavior evaluator. Its position as a mediator between self identity and self actor. Individual tends to evaluate on what he has perceived, and subcet ID as well. Self evaluation will determine subjects self-esteem

The example of ideal self evaluation implementation is individual is able to self evaluation with positive label and contribute on behavior self confidence. it didn't occur on subject ID, behavior emerge controversial. Subject gives negative label on himself, do not feel unsatsfaction, always think that he shoud get more than todays so it has the over careful personality. Subject thinks that he is close with the surrounding. The key of ideal evaluation is self esteem forming.

Self evaluation dimension is related in self actualisation. (Agustiani 2006) because it covers self dimension, self identity and self behavior. It is related to high self satisfaction and conscious on reality. It is emerged from subject's daily with the intervention process given.

Self evaluation dimension is divided into 2 indicators and it is split into 8 statement items. The measurement on baseline A1 phase, subject got lowest score, 17 and 16 of the maximal score 40. Respondent majority choosed the answer disagree on the question 
proposed so it has score 2 on each statement items.

2. External aspect discussion

Self concept external aspect studied William H. Fitts (dalam Agustiani, 2006:138) is divided into 5 dimensions in external aspect. Then, make questionnaires to measure subject self concept. The result of the research in details in each dimension of external aspect can be seen as follows:

a. Self physics

Self physics involves one perception on himself physically. The perception on his health, performance (handsome, ugly, interesting, uninteresting) and physical condition (tall, short, fat, thin)

Behavior emerged before therapy on Subject ID showed that ID didn't like his physical condition nowadays. He is different than normal person because his legs got accident and becomes permanent disability. The impact on it, subject is disable to walk He is crippled and it becomes kids joke $n$ his surrounding environment. ID. It is not convenient to feel and its impact on subject perception considering that he is not perfect person like others who have complete body and has good function.

Self physics dimension is divided into 2 indicators and it is split into favorable and unfavorable 8 statement items. The measuemnet of baseline A1 phase, he got lowest score 13 , but on baseline A1, both subjects got score 25 from maximum score 40. The response change is influenced by the atmosphere of the time measurement conducted on daily life.

Respondent Majority choose disagree so get score 2 on each statement items. The measurement result of first baseline shows that he was unaccaptabe on physics condition now and always think of his performance. But it is different when the reasrcher do indept interview to subject ID, he said that his physic condition now is not comfortable.

The effect of drug abused consumption made subject health condition getting worst so one day subject is referred to puskesmas Jayagiri village becauses caught by the security when using hemp plant with drug used friends. The effect of depressant and stumaulant drug abused toward his physical characteristics, melancholy eye and watered, stuttered talk and always sleepy condition. Physical performance is not taken care, he seldom takes a bath and careless urinate.

Interventin conduct gives the significant effect on the grow on subject physic dimension. The findings intervention phase score shows the increasing of each session. The first session score is 28 , the second is 26 , the third session is 31 , the fourth session is 30, and the fifth session is 34. The intervention conduction process is done when he is in abstinent. The physicaly effect emerged such as the changes of subject's performance and fresh face.

He counting of baseline A2 phase, subject got perfect score and it shows that self-physic dimension is perfect, 39 .

b. Self moral-ethics

It is one's perception on himself from the view of morale and ethics value considering standard. It involves one perception on the relationship to god, satisfaction on religious life and morale value hold., good or bad person.

Self moral-ethics dimension is divided into 2 indicators, that indicators are divided into 8 favorable and unfavorable statement 
items the measurement on first and second baseline A1 phase got the same score, 18 of the maximum score 40. Response consistency given by the subject ID reflected that he experienced of low self cocncept on the self moral-ethics dimension. He never does his religious tenet, praying, fasting and others. He drinks alcoholic drink on the night of iedul fitri with frindes of drug used.

The counting result of baseline A2 phase shows the increasing significant score, 38 Behavior emerged after intervention, subject ID tried to join spiritual activity provided in neighnorhood 'environment or village level. Subject ID tried to appreciate others effort to ask subject to invole in the neighborhood without being suspicious toward them.

\section{c. Self -personal}

Self-personal is the feeling and perception toward personal value. It is not influenced by physical condition or the relationship with others, but how far is individual satisfied on his personality or how far he feels himself as adequate personal.

Unsatisfied feeling on personal achievement and on what was going on made him worried nowadays. He didn't think that God bless us with the strength and weakness. In this case, he didn't understand how to search for self potention and to develop it so it arouse percepsion that God is unfair in creating him without streghth.

Self personal dimension is divided into 2 indicators. that indicators are divided into 8 items of favourable and unfavourable statements. tHe measurement on baseline phase subject A.1 has low score, 19, but on the score of baseline A1 both subjectsgot score 25 of maximum score 40. The answer change is influenced by atmosphere at the time of conducting measurement that is done on subject's daily life.

\section{d. Family self}

Family self shows feeling and one self esteem in his status as family member and close friends. The part shuws how far is someone feeling adequate to himself as family member and its the role of function as member of family.

The beginning condition before conducting intervention seen that there is distanly relation between he and his father, subject's past Trauma because his father was always mad at him and he lwas beaten by him. His mother was often mad at him because of uncertain reason. But nowadays, she is more calmed and start to talk to him. It was the role of family hope program who provided routine meeting $\mathrm{P} 2 \mathrm{~K} 2$. Which one of the material is child care.

Emotional condition in family influence child; growth condition. Subject feels uncomfortable at home and therefore lpppk for other places which can accept his condition now. Trapped in drug used. It is not a new thing for him because he often saw his father drunk at his house with his friends. Of course, it can be a model for the children who see it.

Modeling is one of aspects in determining behavior. Next, Albert Bandura (1986) describes modeling is a structured behavior. Children will do anything he sees, not anything he hears from his parent. The basics is believed that occurs at Subject ID.

The result of baseline Alcounting gets score 24 of score 40, The score is still low. Till that the time of baseline A2 counting 
increases of score, 39. It has the impact on it because there is behavior change emerging in family.

e. Self-social

This part is individual evaluation on his interaction with others or the surroundings around him. The forming of individual evaluation on the parts of self in external dimension is influenced by evaluation and interaction with others. Someone cann't evaluate that he has best physics without the reaction from others shows that physically is charming. And one can't say that he has good self personal without response or reaction of others surroundings which shows he is indedd own good personality.

The subject; neighborhood has been different from the past. When he was a child many neighbors care and often ask him to play, where as is different nowadays. Because of economic condition and physic condition makes him to be bully by the kid in his environment. Environment uncomfortable that gave him a stigma. It makes him think that the environment is something wicked.

The counting of baseline A1 shows low, 17 of the maximum score, 30 . Self social dimension has only one indicator and is divided into 6 staements. It shows that Subject can not accept social environment and it is seen from subject behavior who does not want to socialize with them.

The counting of baseline A2 shows the increasing of answer to be 29. Behavior emerging after doing intervention intervensi is subject ID wants to socializise with the society by the method of joining youth organization and participates as a member.

3. The study of implementation of Rasional
Emotif Terapi (RET)

Rasional Emotif Terapi (RET), whis is now known as RET Therapy has the purpose of diminishing belief distructed himself. Albert Ellis (1998:311).

Rasional Emotif Terapi is psichoterapy ideology based on the assumption that human being was born with the potention, not only rational thinking and fair but also irrational thinking and wicked. Human being tend to self maintain, to be happy, think and say to love,to join others and grow and self actualization.

Rasional Emotif Therapy is conducted 5 sessions or 5 times of meeting with the target of increasing self concept on subject ID.mThe behavior target changed is the subject's irrational thinking described internal and external aspects (William Fitts) in order to stop him to cosuming drug abused. The implementation of rasional emotif terapi is conducted with the theory $\mathrm{ABCDE}$ combined with the technique of emotional support and positive thinking.

The result if beginning assessment shows there is maladaptive behavior showed by subject namely:

a) Sensitive on criticism

b) Responsive on praise

c) Tends to be hypercritics

d) Tend to feel unfavorable by others

e) Pessimistic on competation

Based on the depth interview and observation, finally the researcher decided to take self concept variable combined with the William H. Fitts theory about self concept.

Based on the re-asesment done on subject ID, there is two aspects of self concept disorder namely internal and eksternal aspects the technique of Rational 
Emotif applied on subject ID who is a drug abused user, he had succeded in increasing subject's self concept.

The research conducted by wiryo nuryono (education journal applying rational emotif therapy to increase self worth and self confidence of the victim of HIV/AIDS the year 2014) described that there was the increasing score before and after the treatment therapy of rational emotive to respondent. In line with that, there is the same variable applied namely rational emotive therapy.

The application of RET conducted to increase self worth and self confidence whis is part of self concept. the application of RET is able to increase score that at first the respondent felt unworthy and after the treatment becomes more worth and be able to socialize actively in the surroundings.

William D. Brooks (dalam Rini,2002) depicted things that one of the success of RET implementation on increasing self concept based on ones characteristics has positive self concept :

a) Beleive to his ability to cope the problem.

b) Individual has self confidence so he is able to cope facing problemi.

c) Feel in line with others.

d) Accept without feeling embarrased.

e) Realizing that everyone has various feelings and wills and behavior that is not agreed by the society

f) Be able to recover because he is able to reveal personality aspects that is unfavorable and try to change it.

After giving RET intervention conducted in 5 sessions of meeting, the increasing of self concept subject occurs., subject's mad aspect it occurs low score on all aspects now enters to high self concept category Implementation of RET is said to be effective to increase self concept on subject ID.

\section{Hypothesis test}

Hypothesis test done on each aspect namely, Skor mean yang diperoleh pada tahap baseline A1 pada aspek internal adalah 0.36 , sedangkan mean pada tahap intervensi adalah 4.86, dan nilai selisih mean dari keduanya yaitu 4,45 . Nilai selisih tersebut lebih besar dari nilai 2 SD yang bernilai 3,25.

Test Hipotesis is accepted when mean of the different score is bigger than deviant standard score. It can be said that intervention done is significant on internal aspect. It describes that the implementation of RET works to increase self concept of subject ID on internal aspect.

Mean score on baseline A1 stop on external aspect is 1.92, however mean on intervention level is 4.84 , and the defferent mean of both is 2,92 bigger than 2 SD scoring 2,34 .

\section{Main Hypothesis test}

Mean score got on baseline A1 stage on self concept is 0.15 , where as mean on the intervention stage is 4.75 so getting selisih fromi both is 4,60. Nilai selisih is bigger than grade 2 SD yang bernilai 4,51 , So it is said that intervention conducted significantly on internal dan eksternal aspects (the way how to count is terlampir). It says that the application of Rasional Emotif Terapi (RET) works to increase self concept on subjet ID

On the main hypothesis test done with 2 ways namely statistics test test $\mathrm{t}$ :

Main Hypothesis: 4.75-0.15 = $4.60>4.51$ (nilai 2SD) so the change is significant Hypothesis $1: 4.86-0.36=4.45>3.25$ (nilai 2SD) so the change is $\mathrm{n}$ significant 
Hypothesis $2: 4.84-1.92=2.92>2.34$ (nilai 2SD) so the change is significant conclusion: $\mathrm{H} 1$ accepte and $\mathrm{H} 0$ rejected

\section{CONCLUSION}

This research aimed to test of implementation of Rasional Emotif Terapi (RET) model to subject ID on the increasing self concept of drug ebused in Jayagiri Village lembang sub district.

The implementation of Rasinoal Emotif Terapi (RET) technique on subject ID having drug abused problem works to increase self concept emerging on subject ID. The implementation of intervention is conducted in 5 sessions in 7 days. The increasing of self concept occurs almost in every session.

Score got from the research result namely, the first baseline A1 internal aspect got score 45 and external aspect got score 104 , total score is 149 . Baseline A2 both external aspects and internal got score 42 and external aspect with the score 95 the total score is 137.

Score got on the intervention B phase is as follows, The first session got total sccore 192. The second session got total score 213 . The third session got the total score 234 . The fourth session got total score 232. And the fifth session got total score 271 .

Score got based on research result is the first baseline A2, internal score 106 and external aspect score, 178.

The research result shows that implementation of Rasional Emotif Terapi (RET) has impact on the increasing self concept of Subject ID that can be seen from early baseline A1 data, intervention B and baseline A2 shows the increasing of graphics on behavior target, it is strengthen with the hipotesis test that shows that the implementation of RET influences significantly on the increasing self concept of subject ID.

\section{REFERENCES}

Arden lee, C. Elaine wirrel. 2008. Pediatric neurology: self-concept in adolescent with drug users; biologycal and social correlates. volume 38. Alberta: Canada (Jurnal internasional).

Badan Narkotika Nasional. 2015. Data Pengguna NAPZA Dan Jenis Obat Yang Dikonsumsi. BNNP Jawa Barat.

Beck, A.T. 1978. Cognitive Therapy And Emotional Disorder. New York. International University Press. Inc.

DuBois, B \& Miley, K.K. 2014. Social Work An Empowering Profession : $8^{\text {th }}$ Edition. New Jersey : Pearson

H. Agustiani. 2006. Psikologi Perkembangan Pendekatan Ekologi Kaitannya Dengan Konsep Diri. Bandung: PT.Refika Aditama

Hall, Calvin S \& Gardner Lindzey. 1993. Psikologi kepribadian 2 teori-teori Holistik. Jakarta; Kanisius.

Juang Sunanto, dkk. 2006. Penelitian Dengan Subyek Tunggal. Bandung: UPI Press

Julianan Lisa \& Nengah Sutisna. 2013. Narkoba, psikotropika, dan Gangguan Jiwa/Tinjauan Kesehatan dan Hukum. Yogyakarta: Nuha Medika.

J. Marbun. 2017. Pekerja Sosial Dengan NAPZA/Narkoba. STKS Bandung press

Johnson, Jerry L. 2004. Fundamentals of Substance Abuse Practice. Canada. 
Brooks/Cole, A devision of Thomson Learning, Inc

Sugiyono. 2010. Metode penelitian kuantitatif dan kualitatif \& $R N D$. Bandung: Alfabeta.

Sunanto, Juang dkk. 2006. Pengantar Penelitian Dengan Subyek Tunggal, CRICED.

Undang-undang No 35 Tahun 2009 Tentang Narkotika. 